\title{
Studies on polyphenol oxidase in pomegranate (Punica granatum L.)
}

\section{M.R. SHELKE, S.A. FARGADE AND R.V. DARADE}

\author{
Depatement of Biochemistry and Molecular Biology, College of Agricultural Biotechnology, Loni (ITI Campus) \\ Rahata, AHMEDNAGAR (M.S.) INDIA \\ Email : mrshelke.3@gmail.com
}

\begin{abstract}
The present investigation was undertaken to study properties of polyphenol oxidase and monitor changes in polyphenal oxidase activity in Ganesh cultivar of pomegranate during storage. The characterization of polyphenol oxidase in pomeqranate fruit extract with respect to effect of enzyme concentration and substrate concentration was studied . for studying changes in polyphenol oxidase activity during storage, the pomegranate fruits at half yellow stage were freshly harvested and stored at ambient temperature and analyzed after $0,2,4,6,8$ and 10 days of storage. The polyphenol oxidase activity has increased up to $8^{\text {th }}$ day of storage and thereafter, decreased slightly on $10^{\text {th }}$ day.
\end{abstract}

Key words : Ambient, Half yellow stage, Substrate, Enzyme

How to cite this paper : Shelke, M.R., Fargade, S.A. and Darade, R.V. (2014). Studies on polyphenol oxidase in pomegranate (Punica granatum L.). Asian J. Bio. Sci., 9 (2) : 224-226. 